\title{
Suggestions Expressed by the Respondents in Adoption of Transplanting Method of Pigeon Pea Cultivation Practices
}

\author{
Ashok Kumar Melkeri* and Syed H. Mazhar
}

Department of Agricultural Extension \& Communication, Sam Higginbottom Institute of Agriculture, Technology and Sciences, Naini, Allahabad-211 007, U.P., India

*Corresponding author

\begin{tabular}{|l|l|}
\hline \multicolumn{1}{c|}{ A B S T R A C T } \\
\cline { 2 - 3 } \multicolumn{1}{c|}{ Key w ord S } & $\begin{array}{l}\text { Present study was conducted in Kalaburagi district of Karnataka state to identify the } \\
\text { suggestion by the farmers in adoption of transplanting method of pigeon pea cultivation. }\end{array}$ \\
$\begin{array}{l}\text { Knowledge, adoption, } \\
\text { suggestion, pigeon pea } \\
\text { and transplanting }\end{array}$ & $\begin{array}{l}\text { Critical inputs should be given at low price to the small farmers (71.67\%), solve the labour } \\
\text { problem use improved implements (64.17\%), proper plant protection knowledge should be } \\
\text { given in time (56.67\%) and proper marketing facility should be available in the area } \\
\text { (53.33\%), government should try to provide adequate power supply (50.83\%), subsidy } \\
\text { should be provided to green house (45.83\%), improved irrigation facilities should be } \\
\text { provided (43.33\%), technical advice and training should be given at time to time (40.00\%) } \\
\text { and government should try to provide quality seeds in time (23.33\%) were important } \\
\text { suggestion to overcome/minimize the constraints in adoption of transplanting method of } \\
\text { 21 May 2018 } \\
\text { pigailable Online: } \\
\text { 10 June 2018 }\end{array}$ \\
\hline \hline
\end{tabular}

\section{Introduction}

Pulses play an important role in Indian agricultural economy as they are rich sources of proteins and constitute 10 to 15 per cent of India's food grain diet.

Major portion of Indian population belongs to vegetarian group and every person on an average is required to consume 70 to $80 \mathrm{gm}$ of pulses per day in order to maintain good health and physique, according to the recommendations of Indian Council of Medical Research. Pigeon pea [Cajanus cajan (L) Mill sp.] is the second most important pulse crop of India after chickpea. It is cultivated in a multitude of production systems for a diversity of uses - grain as dhal, green seed as vegetable and stalk as fuel wood.

It is an important pulse crop in the country as well as in the state. It is mainly grown in almost all the states and larger portion of the area is in the states of Maharashtra, Uttar Pradesh, Madhya Pradesh, Karnataka and Gujarat.

India is the largest producer and consumer of pulses in the world contributing around 33 per cent of the world area and 25-28 per cent of world production of pulses. About 90 per cent of the global redgram, 75 per cent of bengalgram and 37 per cent of lentil area is 
contributed by India. The country produced 19.78 million tonnes of pulses from 17.21 million hectare area, with an average yield of $694 \mathrm{~kg}$ per hectare during 2013-14. These figures make India the largest producer of pulses in the world (Anonymous, 2012 a). In Karnataka pigeon pea is largely grown in northern parts, especially in Kalaburagi district.

Kalaburagi district is called as pulse bowl of Karnataka and pigeon pea is one of the most important pulse crop grown in this region. The agro-climatic conditions are best suited for pulse crops cultivation.

The area under pigeon pea crop in Karnataka state during the year 2013-14 was 5.95 lakh hectares with the production of 2.57 lakh tones, whereas the total area under the cultivation of pigeon pea in Kalaburagi district is $3,70,523$ hectares and production is $1,32,987$ tonnes.

Recent technological intervention of transplanting method of pigeon pea cultivation is one of the alternate agronomic practices to overcome late sowing and related lower yields of pigeon pea. It is one of the recently adopted techniques in the study region and gaining importance in pigeon pea farming community.

Therefore, study was conducted to identify the constraints faced by the farmers in adoption of transplanting method of pigeon pea and to seek their suggestions to.

\section{Materials and Methods}

The present study was conducted by using expost-facto research design. The study was carried out purposively in Kalaburagi district because the district is considered as pulse bowl of Karnataka state. Kalaburagi district comprises of seven taluks namely, Afzalpur, Aland, Chincholi, Chittapura, Kalaburagi,
Jewargi and Sedam. Out of seven taluks, three taluks namely, Afzalpura, Chittapur and Kalaburagi were purposively selected, because highest area of transplanting was done in these taluks.

The list of transplanting pigeon pea farmers were taken from department of Agriculture. A list of villages was prepared for the selected taluks and from the list four villages in each taluk were randomly selected. From each village, 10 respondents were selected constituting a total sample of 120 respondents.

Based on the frequencies and intensity each particular suggestion was converted in percentage to minimize the constraints. Frequency and percentage were used to analyze the data to draw the meaningful conclusion.

\section{Results and Discussion}

It is observed in the table 2 that the majority $(71.67 \%)$ of the respondents suggested that the critical inputs should be given at low price to the small farmers, followed by $(64.17 \%)$ of the respondents suggested that to solve the labour problem use improved implements, $(56.67 \%)$ of the respondents suggested that proper plant protection knowledge should be given in time, $(53.33 \%)$ of the respondents suggested that proper marketing facility should be available in the area. (50.83\%) of the respondents suggested that government should try to provide adequate power supply, $(45.83 \%)$ of the respondents suggested that subsidy should be provided to green house, $(43.33 \%)$ of the respondents suggested that improved irrigation facilities should be provided, $(40.00 \%)$ of the respondents suggested that technical advice and training should be given at time to time and at lastly $(23.33 \%)$ of respondents suggested that government should try to provide quality seeds in right time. 
Table.1 Suggestions expressed by the respondents to overcome the constraints in transplanting method of pigeon pea

\begin{tabular}{|c|l|c|c|c|}
\hline $\begin{array}{c}\text { Sl. } \\
\text { No. }\end{array}$ & \multicolumn{1}{|c|}{ Particulars } & Prequency & Percentage & Rank \\
\hline 1. & Subsidy should be provided to green house & 55 & 45.83 & VI \\
\hline 2. & $\begin{array}{l}\text { Government should try to provide quality } \\
\text { seeds in time }\end{array}$ & 28 & 23.33 & IX \\
\hline 3. & $\begin{array}{l}\text { To solve the labour problem use improved } \\
\text { implements }\end{array}$ & 77 & 64.17 & II \\
\hline 4. & $\begin{array}{l}\text { The critical inputs should be given at low } \\
\text { price to the small farmers }\end{array}$ & 86 & 71.67 & I \\
\hline 5. & $\begin{array}{l}\text { Improved irrigation facilities should be } \\
\text { provided }\end{array}$ & 52 & 43.33 & VII \\
\hline 6. & $\begin{array}{l}\text { Government should try to provide adequate } \\
\text { power supply }\end{array}$ & 61 & 50.83 & V \\
\hline 7. & $\begin{array}{l}\text { The proper plant protection knowledge } \\
\text { should be given in time }\end{array}$ & 68 & 56.67 & III \\
\hline 8. & $\begin{array}{l}\text { Proper marketing facility should be } \\
\text { available in the area }\end{array}$ & 64 & 53.33 & IV \\
\hline 9. & $\begin{array}{l}\text { Technical advice and training should be } \\
\text { given at time to time }\end{array}$ & 48 & 40.00 & VIII \\
\hline
\end{tabular}

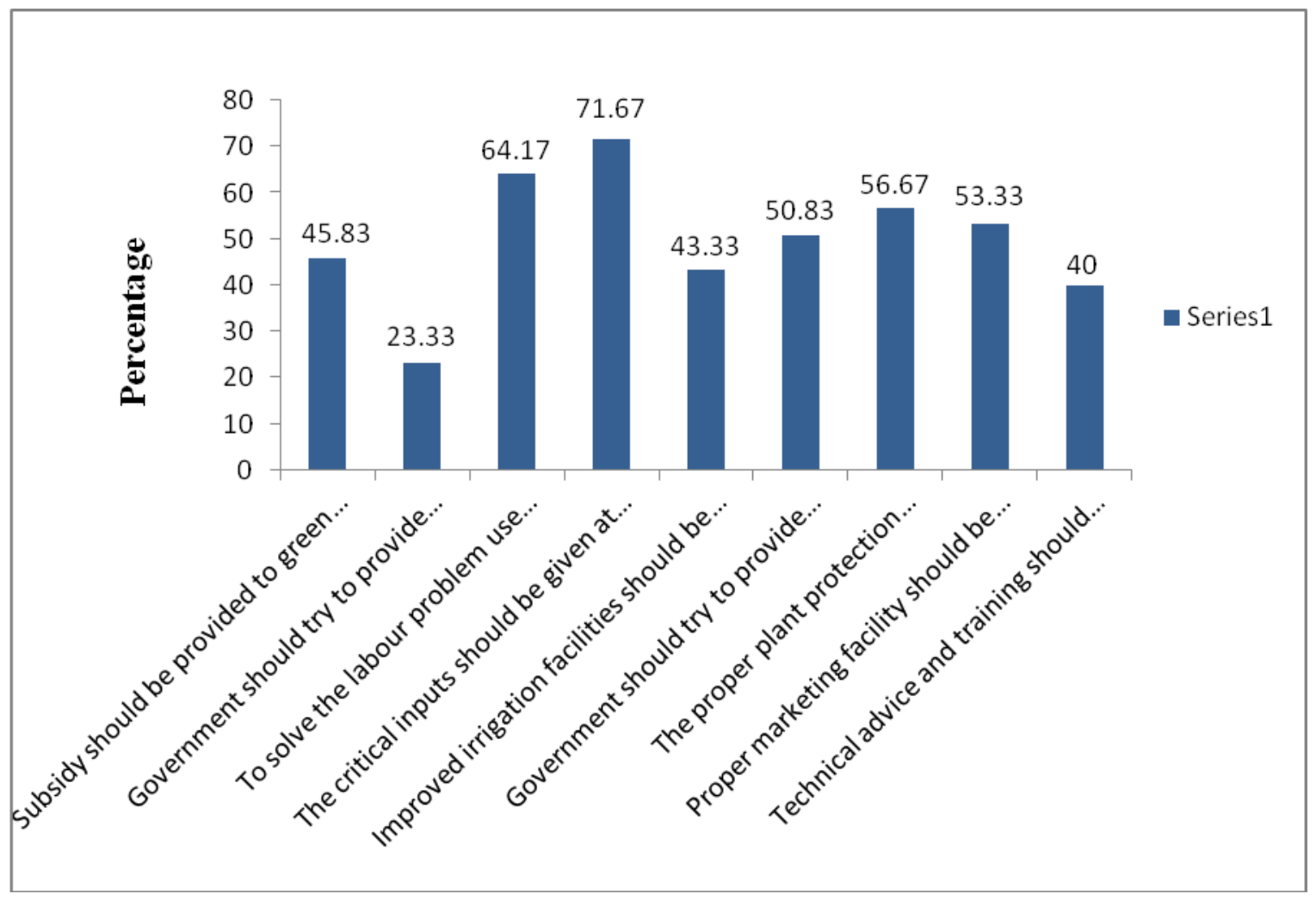


It can be concluded that majority of the farmers suggested that the critical inputs should be given at low price to the small farmers, to solve the labour problem use improved implements, proper plant protection knowledge should be given in time, proper marketing facility should be available in the area, government should try to provide adequate power supply, subsidy should be provided to green house, improved irrigation facilities should be provided, technical advice and training should be given at time to time and Government should try to provide quality seeds in time were important suggestions to overcome/minimize the constraints in adoption of transplanting pigeon pea cultivation.

\section{References}

Maheriya, H.N., Patel, R.C. and Patel, J.B. (2014). Constraints faced by farmers in adoption of recommended paddy production Technology. Gujarat $J$. Extn. Edu., 25(1) : 93-95.
Meena, K.C. (2003). Constraints faced by the farmers in adoption of improved cultivation of cabbage in Udaipur district of Rajasthan. Indian Research Journal of Extension Education, 3(2): 69-71.

Rahman, M. M. (2012). Problem and suggestion for farmers' adoption of IPM practices in rice (Oryza sativa L.) cultivation. Bangladesh J.Agril. Res. 37(1):121- 128.

Rahuri. Clothe, G. D., and Borkar, M., 2000, Constraints faced by farmers in adoption of biofertilizers. Maharashtra J. Extn. Edu. 19: 298-299.

Rai, D.P. and Singh, Bhupendra (2010). Extent of knowledge and constraints in cotton production technology in Madhya Pradesh. Indian Research Journal of Extension Education. 10(2): 78- 80.

Tripathi, M. K. and A. P. Kanungo, (2008). Demonstration of integrated pest management technology in rice at farmers' fields. J. Plant Protection Environ. 5 (1):30- 33.

\section{How to cite this article:}

Ashok Kumar Melkeri and Syed H. Mazhar. 2018. Suggestions Expressed by the Respondents in Adoption of Transplanting Method of Pigeon Pea Cultivation Practices. Int.J.Curr.Microbiol.App.Sci. 7(06): 2935-2938. doi: https://doi.org/10.20546/ijcmas.2018.706.345 